\title{
Microbe-enriched compost application on germination substrates of Beilschmiedia roxburghiana, Bouea oppositifolia and Syzygium polycephalum
}

\author{
HENDRA HELMANTO ${ }^{\natural}$, FRISCA DAMAYANTI, DIAN LATIFAH \\ Center for Plant Conservation, Botanic Garden, Indonesian Institute of Sciences. Jl. Ir. H. Juanda No. 13, Bogor 16122, West Java, Indonesia. \\ Tel.: +62-251-8322187, Fax.: +62-215-8322187, ^email: hendraforestugm@ gmail.com
}

Manuscript received: 30 January 2017. Revision accepted: 22 August 2017.

\begin{abstract}
Helmanto H, Damayanti F, Latifah D. 2017. Microbe-enriched compost application on germination substrates of Beilschmiedia roxburghiana, Bouea oppositifolia and Syzygium polycephalum. Nusantara Bioscience 9: 300-305. The success of germination has been an important issue in many forest restoration programs; that is mainly affected by the quality of sowing media. Application of Bioposka compost (microbe-enriched compost) in the sowing media was hypothesized to increase the success of the germinating and transplanting also. The research aimed at investigating the effect of Bioposka compost to the germination and the seedling growth of the study species. The complete-randomized research design was used for three sowing media, i.e., sand, Bioposka compost and the mixture of sand: compost (1: 1 ratio) of tree species i.e., Syzygium polycephalum, Bouea oppositifolia and Beilsmedia roxburghiana. The variables observed were total and normal germination capacity, first germination, final germination, germination rate, germination simultaneity and seedling growth. The results were analyzed using STAR (Statistical Tool for Agricultural Research). In addition, the microbial abundance of bacteria, fungi, and yeast in each media were calculated using the spread-plate methods. The germination and seedling growth responses were varied between the different media. The germination capacity and seedling growth of Syzygium polycephalum and Bouea oppositifolia were lower by microbe-enriched compost. By contrast, the germination capacity and the seedling growth of Beilsmedia roxburghiana were not significantly different. Moreover, the microbe-enriched compost application increased the abundance of bacteria, fungi, and yeast in the media.
\end{abstract}

Keywords: Beilschmiedia roxburghiana, Bouea oppositifolia, compost, microbe, Syzygium polycephalum

\section{INTRODUCTION}

Germination and early seedling growth are an important phase of a plant lifecycle. According to Koornneef et al. (2002), germination and seed dormancy are an adaptive strategy of tree plant regeneration. Germination substrates are essential for sowing seeds in nurseries (Akbar 1992; Lakitan 2004; Fahmi 2013). Deforestation and plant overexploitation made many species lost and become rare. Conservation strategy also needs technology applied and innovation to enhance the impact of sustainability. Developing germination process must be applied, especially on species which uncultivated like Beilschmiedia roxburghiana, Bouea oppositifolia, Syzygium polycephalum, etc. because uncultivated species are more susceptible than cultivated species to be extinct.

Beilschmiedia roxburghiana (Lauraceae) is a subtropical tree, which lives at 200-400 m altitude (Long 1985; Turner 1995). This species spread in China, Bhutan, India, Myanmar, Nepal, Thailand (Li et al. 2008; Liu 2013) and Indonesia. Its wood is hard and has multiple usages in construction, boat and paper industries. In pharmacology, the terpenoid compound $\alpha$-amirin from $B$. roxburghiana stem bark exhibits insecticidal and cytotoxic activities (Zetra and Prasetya 2007). Liu (2013) said populations of $B$. roxburghiana have become increasingly fragmented in recent years due to deforestation and environmental deterioration caused by economic development in China. Therefore, need to design effective conservation programs for the species. Bouea oppositifolia (Anacardiaceae) famous namely burmese plum, marian plum, marian tree, gandaria (Indonesia). This species is indigenous to the Andaman Islands, Myanmar, Laos, Cambodia, Thailand to Vietnam and South-China (Yunnan, Hainan), Indonesia (Sumatera, Java, Borneo) and Malaysia (Lim 2012) and become an extremely rare mango taxon from the South Andaman (Damodaran et al. 2013). Indonesian people use this fruits for seasoning and some food. Syzygium polycephalum (Myrtaceae) is one of many kinds species which developed in pharmacology. It was reported to lower high blood pressure and high cholesterol level and it exhibits antioxidant activity (Florido and Cortiguerra 2003). A recent study reported that a decoction of the bark is used for the treatment of dysentery (Roosita 2008).

Sands is a common germination substrate for sowing seeds in nurseries (ISTA 2015). However, it lacks nutrients that is immediately required after the seedlings were early established before transplanting. Furthermore, sands are porous which had good aeration and drainage (Fahmi 2013). These characteristics of sands may dry out quickly in some cases that may lead to decrease the seedling quality for transplanting. Therefore, a compost may be added to sowing/germination substrates to improve the quality of early-growth seedlings. This compost is normally used for fertilizing the Garden's living collections. Ekasari (1994) reported that the compost application promoted the germination of candlenut seeds (Aleurites moluccana). Quassia indica and Clausena excavata exhibited the 
highest normal and total germination capacities using compost and sand+compost mix (Damayanti and Helmanto 2015; Helmanto et al. 2015). The mixture of soil and compost had also shown higher germination capacity of Morinda citrifolia $(88.7 \%)$ than those sown in sand i.e. 74.7\% (Muniarti and Suminar 2006).

This research aimed to investigate the effect of microbe-enriched compost Bioposka application on the germination and seedling growth of three tree species Syzygium polycephalum (Myrtaceae), Bouea oppositifolia (Anacardiaceae), Beilschmiedia roxburghiana (Lauraceae).

\section{MATERIALS AND METHODS}

\section{Germination}

This research was conducted in the glass house of Seed Bank Unit, Center for Plant Conservation Bogor Botanic

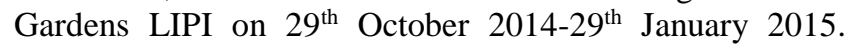
Materials used were the seeds of Syzygium polycephalum (Myrtaceae), Воиеа oppositifolia (Anacardiaceae), and Beilschmiedia roxburghiana (Lauraceae).The research was designed in a completely randomized design. Three of the treatments used a compost i.e. Bioposka which is enriched by a certain amount of nutrients $\left(\mathrm{N}\right.$ total $0,66-0,84 \% ; \mathrm{P}_{2} \mathrm{O}_{5}$ $\left.0,15-0,18 \% ; \mathrm{K}_{2} \mathrm{O} \quad 0,17-0,21 \%\right)$, Beyonic Startmik@ produced by Center for Plant Conservation Botanic Gardens-LIPI in collaboration with Research Center for Biology). Bioposka is produced by Bogor Botanic Gardens Compost Unit using litter collected across the garden. The experiments applied to the germination substrates treatments (the microbe enrichment criteria were based on Table 1-3) as follows: less moist, no microbe media (5.1\% moisture, $\mathrm{pH}$ 7.0), moist, microbe enriched media (the mix of sand and compost 1: 1 ratio, $24.4 \%$ moisture, $\mathrm{pH} 6.9$ ), and very moist, microbe enriched media (42.6\% moisture, $\mathrm{pH}$ 7.0) and; with 3 species trees, each species using two replicates and10 seeds in every experimental replication unit due to the limited availability of ripe fruit.

Moisture levels, acidity levels, and microbial abundance were used to characterize the sowing media properties. The moisture levels of the sowing media were determined based on the media-sample percentage of volume on the $8.6 \mu$ pore diameter $(\mathrm{pF} 2.54)$. Acidity levels were measured using a soil tester (Demetra, Japan).

The variables of germination observed were the total germination capacity, normal germination capacity, first germination, final germination, germination rate and germination simultaneity (Bewley and Black 1994; ISTA 2015). Seedling vigor determined at the end of the observation period (29 $9^{\text {th }}$ January 2015). The data were analyzed by analysis of variance (ANOVA) using STAR (Statistic Tool for Agricultural Research). The formulas used to calculate total germination capacity, normal germination capacity, germination rate and germination simultaneity are as follows (Draper et al. 1985):

$$
\text { Total germination capacity }=\frac{n}{N} X 100 \%
$$

Normal germination capacity $=\frac{n(\text { normal })}{N} X 100 \%$

Germination rate $=\frac{\Sigma \mathrm{n}}{n x t}$

Germination Simultaneity $=\frac{\Sigma \mathrm{n}}{\Sigma\left[(T-t)^{2} \times n\right]} \times 100$

Where,

$\mathrm{T}=\frac{\Sigma \mathrm{n}}{\Sigma\left[(\mathrm{T}-\mathrm{t})^{2} \times \mathrm{n}\right]} \frac{\Sigma(\mathrm{t} \times \mathrm{n})}{\Sigma \mathrm{n}}$

$\mathrm{N}=$ number of germinated seeds

$n=$ number of survived seedling

$\mathrm{n} \times \mathrm{t}=\mathrm{n}$ germinated seeds on day- $\mathrm{t}(\mathrm{t}=1,2,3, \ldots$.

\section{Microbial analysis}

Microbial analysis was conducted in Research Center for Biology (Department of Microbiology) Indonesian Institute of Sciences. The abundance of bacteria, fungi, and yeast was analyzed using the spread-plate methods. The bacteria abundance was determined by using $10 \mathrm{~g}$ samples of the three sowing media in an Erlenmeyer flask which was diluted by adding $90 \mathrm{~mL}$ purified water $\left(10^{-1}\right.$ dilution) and homogenized by using a vortex; this dilution method was repeated until $10^{-6}$ dilution. The $10 \mu \mathrm{L}$ suspension of the $10^{-4}, 10^{-5}$ and $10^{-6}$ dilution was taken and spread into the frozen Nutrient Agar (NA) growth media in a petri dish (three replicates). After 48-72-hour incubation, the number of the bacteria colony was calculated then multiplied by the dilution factor. The abundance of fungi was examined by spread method and calculated by applying TPC (Total Plate Count) method. The fungal colony of each seed-sowing media was sown in rose bengal chloramphenicol agar medium; then the average density of colonies (Colony Forming Unit per milliliter; CFU/mL) developed in each agar medium on the $10^{-2}, 10^{-3}, 10^{-4}$ dilution (three replicates each) was calculated. The yeast abundance was also determined using spread method and calculated by undertaking TPC (Total Plate Count) method. Yeast colony from each seed-sowing media were grown in rose bengal chloramphenicol agar medium and the average density of colonies (Colony Forming Unit per milliliter in CFU/mL) on the $10^{-1}, 10^{-3}, 10^{-5}$ dilution with three replicates was calculated.

\section{RESULTS AND DISCUSSION}

\section{Results}

The responses of the three species varied to the sowing media with and without microbe-enriched supplementation (Table 1 and Figure 1). Analyze by compile all species shown that the different responses are demonstrated by the normal germination capacities, first germination, germination simultaneity and seedling height of $S$. polycephalum. The sand had the highest normal germination in S. polycephalum, i.e. $40 \%$ compared to $20 \%$ 
germination with the addition of microbe-enriched compost (Table 2). On the other hand, the compost had the lowest germination in $S$. polycephalum, i.e. 5\% total germination capacities, then the germinating seeds died after 40 days i.e. $0 \%$ normal germination capacity. The first germination of seed sown in the sand was also earlier (19 day after sowing) with higher seedlings. The germination simultaneity was not significantly different between the sand and compost application.

Although the differences were not significant, through tabulation data calculation, microbe-enrichment media show increased the total germination capacity and normal germination capacity value Bouea oppositifolia. The effects of sowing media on the germination of $B$. oppositifolia were various (Table 3 ). The microbe-enriched gave the highest germination capacity of B. oppositifolia, i.e. $65 \%$. Normal germination capacity was also not different (Table 3 ). By contrast, the seedling had shown the highest height in the sand (lest moist-microbe media) i.e. $13.93 \mathrm{~cm}$ after 90 days $[\mathrm{F}(2,5)=12.42, \mathrm{p}<0.05]$.

The highest total and normal germination capacity of Beilschmiedia roxburghiana were $85 \%$ and $80 \%$, that means there is $5 \%$ abnormal germinating seed, respectively in the microbe-enriched compost; although the results were not significantly different among treatments (Table 4). On the other hand, moist-microbe enrichment media showed lower total germination capacity, i.e. $70 \%$ which was similar to the normal germination capacity.

The result of microbial analysis reported in Table 5. The very moist, microbe-enriched media has the highest abundance of bacterial i.e. $8.1 \times 10^{6} \mathrm{CFU} / \mathrm{mL}$. The less moist, no microbe-enriched media is the lowest value on bacterial abundance i.e. $3.1 \times 10^{6} \mathrm{CFU} / \mathrm{mL}$. Table 6 presented the fungal colony densities from all media. The moist, microbe-enriched media have the highest fungal colony is i.e. $85388,89 \mathrm{CFU} / \mathrm{mL}$, and the lowest one is in the very moist, microbe enriched media. Yeast content showing at table 7 , by comparing each media, the less moist no microbe treatment has biggest yeast abundance i.e. $446.67 \mathrm{CFU} / \mathrm{mL}$ and the lowest one is moist, microbe enriched 16,67 CFU/mL.

Microbe content analysis was done to determine the fungi, bacteria and yeast content in each sample media. This analysis showed the variation of microorganism contains in media. The very moist, microbe-enriched media has highest bacterial content compare to other media i.e. $8.1 \times 10^{6}\left(\mathrm{CFU}^{1} / \mathrm{mL}\right)$. In other hands, this media has the low fungi and yeast colony number. Moist, microbe enriched media has highest fungi colony contain i.e., 85388.89 CFU ${ }^{1}$. Less moist, no microbe media has highest yeast colony contenti.e. $446.67 \mathrm{CFU}^{1}$.

\section{Discussions}

The three species studied responded differently to the sowing media with and without microbe-enriched supplementation (Table 1). The normal germination capacities, first germination, germination simultaneity and seedling height of $S$. polycephalum were significantly different among the varied sowing media. The sand may promote the normal germination of $S$. polycephalum i.e., $40 \%$ compared to $20 \%$ germination with the addition of microbe-enriched compost (Table 2).

Table 1. The recapitulation analyses of variant result by various treatment effect sowing media on the germination of Syzygium polycephalum, Bouea oppositifolia, and Beilsmedia roxburghiana

\begin{tabular}{|c|c|c|c|c|c|c|c|}
\hline Species & $\begin{array}{c}\text { Total } \\
\text { germ. capacity }\end{array}$ & $\begin{array}{c}\text { Normal } \\
\text { germ. capacity }\end{array}$ & $\begin{array}{l}\text { First } \\
\text { germ. }\end{array}$ & $\begin{array}{l}\text { Final } \\
\text { germ. }\end{array}$ & $\begin{array}{c}\text { Germ. } \\
\text { rate }\end{array}$ & $\begin{array}{c}\text { Germ. } \\
\text { simultaneity }\end{array}$ & $\begin{array}{c}\text { Seedling } \\
\text { height }\end{array}$ \\
\hline $\begin{array}{l}\text { S. polycephalum } \\
\text { B. oppositifolia } \\
\text { B. roxburghiana }\end{array}$ & ns & ns & ns & ns & ns & ns & ns \\
\hline Each species ana & sult & $*$ & * & $n s$ & $\mathrm{~ns}$ & $* *$ & $* *$ \\
\hline B. oppositifolia & ns & ns & ns & ns & ns & ns & $*$ \\
\hline B. roxburghiana & ns & ns & ns & ns & ns & ns & $\mathrm{ns}$ \\
\hline
\end{tabular}

Note: $*=$ significant $(\mathrm{p}<0,05) ; * *=$ significant $(\mathrm{p}<0,01) ;$ ns $=$ not significant $(\mathrm{p}>0,05)$

Table 2. The treatment effect of various sowing media on the germination of Syzygium polycephalum*

\begin{tabular}{lcccc}
\hline Treatments & $\begin{array}{c}\text { Normal germination } \\
\text { capacity }(\boldsymbol{\%})\end{array}$ & $\begin{array}{c}\text { First germination } \\
(\text { day })\end{array}$ & $\begin{array}{c}\text { Germination } \\
\text { simultaneity }\end{array}$ & $\begin{array}{c}\text { Seedling height } \\
(\mathbf{c m})\end{array}$ \\
\hline Less moist, no microbe & 40 & $19 \mathrm{a}$ & $0.22 \mathrm{~b}$ & $8.22 \mathrm{a}$ \\
Moist, microbe enriched & 20 & $68 \mathrm{c}$ & $0.13 \mathrm{~b}$ & $5.7 \mathrm{~b}$ \\
Very moist, microbe enriched & 5 & $40 \mathrm{~b}$ & $2.49 \mathrm{a}$ & $0 \mathrm{c}$ \\
\hline
\end{tabular}

Note: *Means with the same letters are not significantly different $(p>0.05)$ 
Table 3. The treatment effect of various sowing media on the germination of Bouea oppositifolia*

\begin{tabular}{lcc}
\hline \multicolumn{1}{c}{ Treatments } & $\begin{array}{c}\text { Total germ. } \\
\text { capacity } \mathbf{( \% )}\end{array}$ & $\begin{array}{c}\text { Seedling } \\
\text { height }(\mathbf{c m})\end{array}$ \\
\hline Less moist, no microbe & 40 & $13.93 \mathrm{a}$ \\
Moist, microbe enriched & 45 & $10.18 \mathrm{~b}$ \\
Very moist, microbe enriched & 65 & $8.85 \mathrm{~b}$ \\
\hline Note: *Means with the same letters are not significantly different \\
$(\mathrm{p}>0.05)$
\end{tabular}

Table 4. The treatment effect of various sowing media on germination of Beilsmedia roxburghiana*

\begin{tabular}{lcc}
\hline \multicolumn{1}{c}{ Treatments } & $\begin{array}{c}\text { Total germ. } \\
\text { capacity }(\boldsymbol{\%})\end{array}$ & $\begin{array}{c}\text { Seedling } \\
\text { height }(\mathbf{c m})\end{array}$ \\
\hline Less moist, no microbe & 75 & 18.25 \\
Moist, microbe enriched & 70 & 16.31 \\
Very moist, microbe enriched & 85 & 13.41 \\
\hline
\end{tabular}

Note: *Means with the same letters are not significantly different $(\mathrm{p}>0.05)$

Table 5. Bacterial abundance of various types sowing media*

\begin{tabular}{lc}
\hline Samples & Abundance $\left(\mathbf{C F U}{ }^{1} / \mathbf{m L}\right)$ \\
\hline Less moist, no microbe & $3.1 \times 10^{6}$ \\
Moist, microbe enriched & $3.7 \times 10^{6}$ \\
Very moist, microbe enriched & $8.1 \times 10^{6}$ \\
Negative control ${ }^{2}$ & 0 \\
\hline Note: *CFU = Colony Forming Unit; ${ }^{2}$ Negative control $=$ \\
sterilized-purified water used in dilution process
\end{tabular}

Table 6. Fungal colony densities of various types sowing media

\begin{tabular}{lccl}
\hline Samples & N & $\begin{array}{c}\text { Colony } \\
\text { density* }\end{array}$ & CFU* \\
\hline Less moist, no microbe & 9 & $7,11 \mathrm{a}$ & $15555.56 \mathrm{a}$ \\
Moist, microbe enriched & 9 & $56,78 \mathrm{~b}$ & $85388.89 \mathrm{~b}$ \\
Very moist, microbe enriched & 9 & $4 \mathrm{ab}$ & $17000.00 \mathrm{ab}$ \\
\hline
\end{tabular}

Note: *Means with the same letters are not significantly different $(\mathrm{p}>0.05)$

Table 7. Yeast abundance of various types sowing media

\begin{tabular}{llcl}
\hline Samples & N & Abundance $^{1}$ & CFU* $^{*}$ \\
\hline Less moist, no microbe & 3 & $44,67 \mathrm{a}$ & $446.67 \mathrm{a}$ \\
Moist, microbe enriched & 3 & $1,67 \mathrm{~b}$ & $16.67 \mathrm{~b}$ \\
Very moist, microbe enriched & 3 & $13,33 \mathrm{~b}$ & $133.33 \mathrm{~b}$ \\
\hline Note: *Means with the same letters are not significantly different \\
$(\mathrm{p}>0.05)$
\end{tabular}

However, the compost may inhibit the germination of $S$. polycephalum i.e., 5\% total germination capacities. This may indicate the microbe-enriched compost seemed to inhibit the seedling survival after 40 days. The sand also had stimulated the seeds to germinate earlier (19 days after sowing) and resulted in higher seedlings. The sand and compost application did not affect the germination simultaneity. Mudiana (2006) found that genus Syzygium had a low germination which was $53.33 \%$ total germination capacity and less germinating seeds survived resulting in $6.67 \%$ normal germination capacity using the sand and soil $\operatorname{mix}(1: 1)$.

From all media which used, there are significant differences in high growth rate. Less moist, no microbeenriched media gave the best results in high indicator. During the research time (3 months) seedling can reach high average $8.22 \mathrm{~cm}$ on this media. In other hands, on the moist, microbe-enriched media gave high average $5.7 \mathrm{~cm}$. (Table 2)

The microbe-enriched compost appeared to stimulate the germination of B. oppositifolia i.e., $65 \%$ total germination capacity (Table 3). The moist, microbeenriched media shown $40 \%$ total germination capacity, it is mean increased $12.5 \%$ from total germination on lest moist-microbe media which usually used. Also on very moist-microbe enriched shown $65 \%$ total germination capacity, it is mean increased $62.5 \%$ from lest moistmicrobe media. However, the sand (lest moist-microbe media) may promote the seedling growth.

The microbe-enriched compost resulted in the highest total and normal germination capacity of Beilschmiedia roxburghiana i.e., $85 \%$ and $80 \%$ respectively (Table 4 ). It means the total germination increased on very moistmicrobe enriched media 13,3\% compared to the less moist media. However, the compost application may not enhance the seedling growth; although the differences were not significant. By contrast, the moist-microbe enrichment media shown to decrease total germination capacity until $6.6 \%$ which was almost similar to the normal germination capacity indicating the seedling survival was maintained.

The three study species responded differently to the microbe-enriched sowing media. Thus the microbeenriched compost can be a good sowing media in some species for transplanting success. Furthermore, the moisture level of sowing media tends to affect the germination rather than the seedling growth. The moisture level is essential in imbibition process preceded the onset of germination. Imbibition is an increase of seed water content required to metabolism for seed germination (Hartman et al. 1990; Asiedu et al. 2000). This imbibition process occurs as the seed water potential is lower than those seed surroundings, therefore the seeds absorb water to run metabolism for germination (Benech and Sanchez 2004; Soemardi et al. 2009). Germination substrates are essential for seed germination in nurseries including shading houses or greenhouse (Akbar 1992; Lakitan 2004; Fahmi 2013). Growing media useful to buttress the seedling for growing; however, Syzygium polycephalum germination was low in very moist media. The high moisture level of sowing media may attract diseases caused by fungi and or pests attack (Lakitan 1995). 

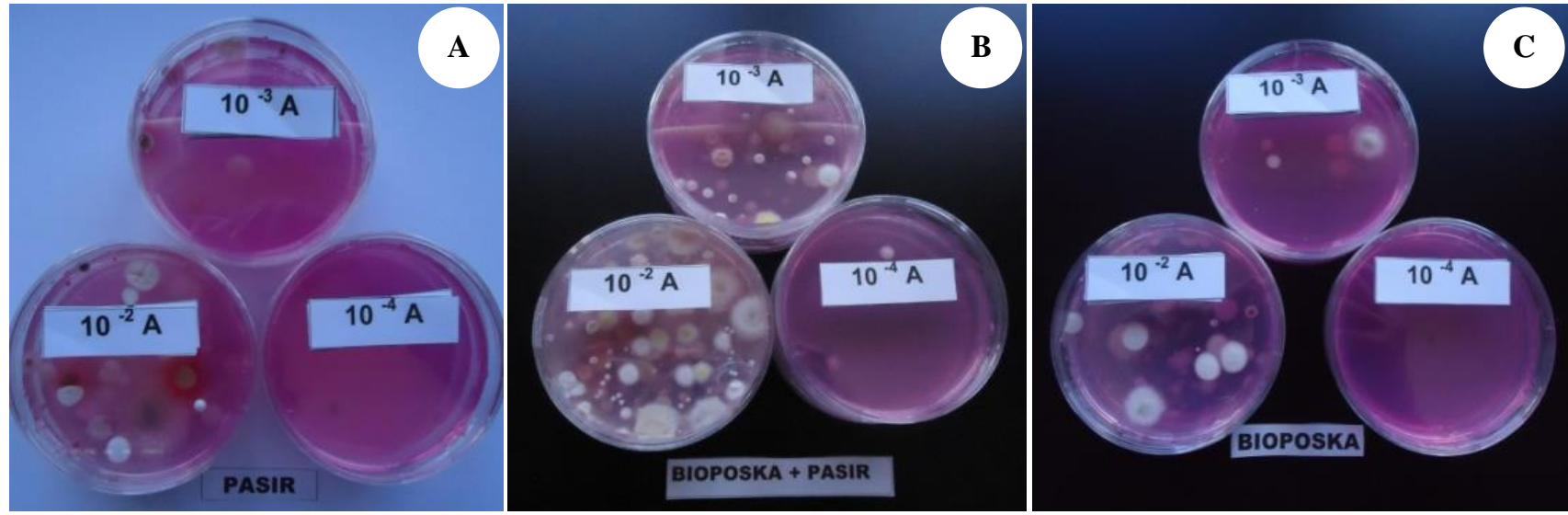

Figure 1. Microbe content analysis. A. Less moist, no microbe media sample microbe counting after 48-72 hour incubation; B. Moist, microbe enriched media sample microbe counting; C. Very moist, microbe enriched media sample microbe counting

On this research, microbe enriched media preferred slower high growth comparing than no microbe media. That is show there is an indication, which enriched media potentially inhibit germination process or early growth. This may be caused by the cotyledon presence. These cotyledons may cause the nutrition provided by the microbe-enriched compost had not been utilized optimally for the early growth of the seedlings. Microorganism presence will inhibit germination process also reported by several researches before. Dormancy can be overcome by gibberellins (Wareing and Saunders 1971), which is claimed to be common microbial metabolite (Brown 1974). In addition to the colonization of seed on the ear or during storage, microorganisms can develop during seed germination, and when the supply of oxygen is limited they can compete for oxygen and inhibit germination (Gaber and Roberts 1969; Matthews and Collins 1975; Lynch and Pryn 1977; Harper and Lynch 1979). Harper and Lynch (1980) report, studies using micro-organisms can either inhibit or stimulate on barley seed germination, or seedling development, under conditions that in the absence of treatment are favorable for these processes and approximate to the seedbed.

The conclusion of this research, microbe-enriched compost did not promote the germination and seedling growth of $S$. polycephalum. The microbe-enriched compost appeared to stimulate the germination of B. oppositifolia; however, the compost may not promote the seedling growth. The microbe-enriched compost appeared to enhance the germination of Beilschmiedia roxburghiana seeds up to $85 \%$. It concluded that the three study species responded differently to the microbe-enriched sowing media. Thus the microbe-enriched compost can be a good sowing media in some species for transplanting success.

\section{ACKNOWLEDGEMENTS}

Thanks, Prof. Rochadi Abdulhadi for his scientific advice during the writing process. The research was funded by DIPA (thematic program entitled: Seed Conservation on Indonesiam Rare Plants, Orchids, and EconomicalPotentially Wild Plants) of Center for Plant Conservation Botanic Gardens, Indonesian Institute of Sciences (LIPI). We also thank the staffs of Seed Bank of Botanic Gardens LIPI and Compost Bioposka Unit for their assistance. Thanks, Research Center for Biology (Department of Microbiology) LIPI for the assistance in the microbial analysis as well as to Center for Soil Research and Development, Ministry of Agriculture, Republic of Indonesia.

\section{REFERENCES}

Akbar A. 1992. Important aspects of tree seed germination test according to ACFTSC. Jurnal Penelitian dan Pengembangan Kehutanan 8 (2): 5 10. [Indonesian]

Asiedu EA, Powell AA, Stuchbury T. 2000. Cowpea seed coat chemical analysis in relation to storage seed quality. Africa Crop Sci J 8 (3): 283-294.

Benech AR, Sanchez RA. 2004. Handbook of Seed Physiology. Applications to Agriculture. Haworth Press Inc. New York.

Bewley JD, Black M. 1994. Physiology and Biochemistry of Seeds in Relation to Germination: Viability, Dormancy, and Environmental Control. Springer-Verlag, New York.

Brown ME. 1974. Seed and root bacterization. Annual Review of Phytopathology, 12.181.

Damayanti F, Helmanto H. 2015. Seed germination and seedling growth of Clausena excavata on Bioposka composting treatment. Pros Semnas Masy Biodiv Indonesia Vol 1 No 4: 856-859. [Indonesian]

Damodaran T, Ahmad I, Nagarajan B. 2013. Bouea oppositifolia-A fast disappearing native mango genetic resource from Andamans: Morphological and molecular evidences. Indian J Hort 70 (2): 161164.

Draper SR, Bass LN, Bould A, Gouling P, Hutin MC, Rennie WJ, Steiner AM, Tonkin JHB. 1985. Seed Science and Technology. International Seed Testing Association, Zurich.

Ekasari P. 1994. Effect of Maturity Level, Planting Media, and Seed Position Planted on Seed Germination Kemiri (Aleurites moluccana Willd). [Hon. Thesis]. Faculty of Agriculture, Bogor Agricultural University, Bogor. [Indonesian]

Fahmi ZI. 2013. Planting Media as External Factors Affecting Plant Growth. Director General of Plantation, Ministry of Agriculture, Jakarta. [Indonesian]

Florido HB, Cortiguerra FF. 2003. Lesser known edible tree species. Res Info Ser Ecosyst 15 (3): 1-8. 
Gaber SD, Roberts, EH. 1969. Water sensitivity in barley seeds. 11 Association with micro-organism activity. J Inst Brewing 75: $303-$ 314.

Harper SHT, Lynch JM. 1980. Microbial effect on the germination and seedling growth of barley. New Phytol 84: 473-481.

Harper SHT, Lynch JM. 1979. Effects of Azotobacter chroococcum on barley seed germination and seedling development. J. Gen Microbio 112: 45-51.

Hartmann HT, Kester DE, Davies FT. 1990. Plant Propagation Principles and Practices. Prentice-Hall, New Jersey.

Helmanto H, Damayanti F, Purnomo DW. 2015. Effect of Bioposka compost in the seed germination process and growth of Quassia indica. Pros Semnas Masy Biodiv Indonesia 1 (4): 852-855. [Indonesian]

ISTA. 2015. International Rules for Seed Testing. International Seed Testing Association, Basserdorf, Switzerland.

Koornneef M, Bentsink, L, Hilhorst, H, 2002. Seed dormancy and germination. Curr Opin Plant Biol 5: 33-36.

Lakitan B. 1995. Horticulture, Theory, Cultivation and Post Harvest. PT Raja Grafindo Persada, Jakarta. [Indonesian]

Lakitan B. 2004. The Principles of Plant Physiology. PT Raja Grafindo Persada, Jakarta. [Indonesian]

Li XW, Li J, van der Werff H. 2008. Beilschmiedia Nees in Wallich, Pl Asiat. Rar. 2: 61, 69. 1831. Flora of China 7: 232-243.

Lim TK. 2012. Edible Medicinal and Non-Medicinal Plants: Volume 1, Fruits. Springer, Berlin.
Liu L. 2013. Isolation and Characterization of Microsatellite Markers in Beilschmiedia roxburghiana (Lauraceae). Appl Plant Sci 1 (8): -. DOI: 10.3732/apps. 1200549

Long DG. 1985. Notes relating to the flora of Bhutan: VIII Lauraceae. Notes R Bot Gard Edinburgh 41: 505-525.

Lynch J M, Pryn S J. 1977. Interaction between a soil fungus and barley seed. J Gen Microbiol 103: 193-196.

Matthews S, Collins MT. 1975. Laboratory measures of field emergence potential in barley. Seed Sci Technol 3: 863-870.

Mudiana D. 2006. Germination of Syzygium cumini (L.) Skeels. Biodiversitas. 8 (1): 39-42. [Indonesian]

Murniati E, Suminar M. 2006. The effects of germination substrate and pre-germination treatments on noni seed (Morinda citrifolia L.) viability and its relation to seed dormancy. Buletin Agronomi 34 (2): 119-123.

Roosita K, Kusharto CM, Sekiyama M, Fachrurozi Y, Ohtsuka R. 2008. Medicinal plants used by the villagers of a Sundanese community in West Java, Indonesia. J Ethnopharmacol 115 (1): 72-81.

Soemardi I, Yudono P, Tohari, Widyawati, Nugraheni. 2009. The permeability and germination of sugar palm seeds (Arenga pinnata (Wurmb.) Merr.). Jurnal Agronomi Indonesia 37 (2): 152-158.

Turner IM. 1995. A catalogue of the vascular plants of Malaya. Gard Bull Sing. 47: 347-757.

Wareing PF, Saunders PF. 1971. Hormones and dormancy. Ann Rev Plant Physiol 22: 261-288.

Zetra Y, Prasetya P. 2007. Isolation of $\alpha$-amylin compound from Beilschmiedia roxburghiana (Medang) plant and its bioactivity test. Akta Kimia Indonesia 3: 27-32. [Indonesian] 